\title{
The Role of Halal Awareness on Purchase Intention of Halal Food: Evidence from Indonesian Working Students
}

\author{
Dewiana Novitasari ${ }^{1}$, Gusli Chidir ${ }^{2}$, Didi Sutardi ${ }^{3}$, Joni Iskandar ${ }^{4}$, Erni Taruli Pebrina ${ }^{5}$ \\ ${ }^{1,3,5}$ Sekolah Tinggi Ilmu Ekonomi Insan Pembangunan, Indonesia \\ ${ }^{2,4}$ STMIK Insan Pembangunan, Indonesia
}

\begin{abstract}
This study aimed to measure the effect of attitude, subjective norm and perceived behavioral control on purchase behavior of working students in a private higher education in Tangerang which are mediated by purchase intention and moderated by halal awareness. Data collection was done by simple random sampling to 410 population of working students. The returned and valid questionnaire results were 211 samples. Data processing was used SEM method with Smart PLS 3.0 software. The results of this study concluded that attitude, subjective norm and perceived behavioral control have a significant effect on purchase intention. Meanwhile, purchase intention have a significant effect on working student purchase behavior, and halal awareness moderated effect of purchase intention on purchase behavior.
\end{abstract}

Keywords: Halal awareness, purchase intention, subjective norms, halal food, theory of planned behavior.

\section{INTRODUCTION}

The need for halal products is currently an important thing for millennial customers, not only those who are Muslims. Halal products are not only food products but also consumable products, such as toiletries, pharmaceuticals, cosmetics and service products such as finance, investment and business. The halal product sector has emerged as one of the most prominent and fastest growing markets. The food industry is becoming more concerned and sensitive about the manufacture and procurement of halal products. Halal products are widely receiving recognition as a scale of food safety and quality assurance (Majid et al., 2015). Therefore, at this time, it is very possible that a product that is considered to provide a high guarantee of halal can lead to consumer interest in buying the product at one time (Listyoningrum \& Albari, 2012).

Several studies have discussed the interest in buying halal products. Among the results of his research are the knowledge and religiosity of consumers who are able to predict consumer attitudes and buying interest towards halal cosmetic products (Abd-Rahman et al., 2015). Purchase interest in halal products with the results of research on subjective norms, attitudes, interpersonal religiosity, and intrapersonal religiosity have an effect on buying interest in halal products (Mukhtar \& Butt, 2012). Attitudes, subjective norms, perceptions of behavior control, and halal image influence the interest in halal shops (Mohd Suki \& Abang Salleh, 2018). Perceptions of product safety and health are able to influence attitudes to the use of halal products, attitudes, subjective norms and perceptions of behavior control can influence buying interest in halal food products, and trust and religiosity can increase the relationship between attitudes of using halal products, attitudes, subjective norms and perceptions of behavioral control towards interest buy halal food products (Elseidi, 2018). Attitudes, subjective norms and perceptions of behavioral control have a positive influence on consumers' intention to buy halal cosmetics (Endah et al., 2017). Attitudes, subjective norms and perceptions of behavioral control have a positive effect on the purchase intention of Muslim consumers who have not extended their halal certificates (Listyoningrum \& Albari, 2012). Religious belief, halal logos, and exposure have a positive effect on awareness of halal products, awareness of halal products and product raw materials have an effect on buying interest in halal products, while Islamic brands have no effect on interest in buying halal products among non-Muslims (Azam, 2016).

This study will use Theory of Planned Behavior (TPB) developed by Fishbein and Ajzen, which states that individual behavior is influenced by behavioral interest (Ajzen, 1991). Interest in behavior itself is a function of individual attitudes toward behavior (Attitude), subjective norms (Subjective Norms), and perceived behavioral control (Perceived Control) (Ajzen, 1991). The findings of this study indicate that there is a significant relationship between awareness and purchasing behavior. Interestingly, it was found that only the dimensions of 
TPB's attitude had a significant relationship with purchase intention, while subjective norms and perceived behavioral control did not show a significant relationship with the consumer intention variable (Bashir et al., 2019). The difference between this study and other previous studies is that it is halalawareness as a moderating variable. Consciousness is the ability to understand, feel, and become aware of events or things. Consciousness is a concept about implying understanding and perception of events or subjects (Aziz \& Chok, 2013). Halal awareness is known based on understanding whether a Muslim is halal, knowing the correct slaughtering process, and prioritizing halal food for them to consume. Awareness to buy and consume halal products is very important for Muslims. This is because products that are certified halal are not only produced by Muslim producers but also handled by a number of non-Muslim groups.

\section{A. Halal}

\section{LITERATURE REVIEW AND HYPOTHESES DEVELOPMENT}

In the context of religion, Islam means submitting to the will of God and to His Law, which means that all daily actions carried out by Muslims are acts of worship. So, to be a good Muslim, daily activities of eating, drinking, socializing, buying, education, promoting and so on must be in accordance with God's rules (Alserhan, 2015). In general, Muslims should consider Islamic rules as a way to live a life that must be lived in every aspect of their life. A Muslim must follow Islamic laws governing their duties, morals and behavior (Alserhan, 2015). Many Europeans think that the term halal only refers to food. The term halal has a broader meaning and refers to Allah's laws. Halal is an Arabic word, which is quoted explicitly in the Qur'an which means permitted and "lawful" (Jonathan \& Liu, 2010). In contrast, haram, refers to what is forbidden, and is considered contrary to the will of God and Prophet Muhammad (Ambali \& Bakar, 2014). For example, gambling, lottery, adultery and gossip are haram while production and acts of kindness, charity and cleanliness are halal (Alserhan, 2015). Therefore, both the concept of halal and haram cover all aspects of Muslim life, not just food consumption and halal which is considered a way of life. This is in line with the opinion that "halal is not just an element of a brand but is an important part of the Muslim belief system and a moral code of ethics with a strong ethical attitude, integral to everyday life" (Jonathan \& Liu, 2010).

Halal is defined as something that is allowed. In English, halal often refers to foods that are permitted under Islamic law (Lada et al., 2009). Every Muslim is obliged to consume halal food. This is related to the existence of the teachings of the Qur'an in Surah Al Maidah verse 88, which states: "And eat of the clean and lawful things that Allah has given you and fear have piety towards Allah in whom you believe." However, the procedures and standards of halal are not only limited to following in the form of explicit teachings, but also on hygiene and quality control. Raw materials, semi-finished goods, and all equipment used must also comply with sharia law and must meet the requirements. The food production process must be monitored and supervised by a competent Muslim inspector (Listyoningrum \& Albari, 2012). Especially in Indonesia, to give confidence to consumers that the products consumed are halal, companies need to have halal certificates from the Indonesian Ulema Council (MUI). This institution supervises products circulating in the community by providing halal certificates, so that products that already have a halal certificate can include a halal label on their products. This means that the product in the process and its contents have passed the examination and are free from elements prohibited by Islamic teachings, or the product has become a halal product category and does not contain haram elements and can be consumed safely by Muslim consumers (Listyoningrum \& Albari, 2012 ).

\section{B. Theory of Planned Behavior}

The theory of planned behavior (TPB) was developed by Ajzen in 1988. This theory proposes a model that can measure how human action is regulated. It predicts the occurrence of certain behaviors, provided the behavior is intentional. Planned behavior theory is a theory that predicts intentional behavior, because behavior can be considered and planned (Ajzen, 2015a). There are several purposes and benefits of this theory, among others, is to predict and understand motivational influences on behavior that are not under the control or will of the individual himself. To identify how and where to direct strategies for behavior change and also to explain in each important aspect some human behavior. This theory provides a framework for studying attitudes toward behavior (Ajzen, 2015a). Based on this theory, the most important determinant of a person's behavior is the intention to behave. The individual's intention to display a behavior is a combination of the attitude to display that behavior and subjective norms. Individual attitudes towards behavior include beliefs about a behavior, evaluation of behavior outcomes, subjective norms, normative beliefs and motivation to comply (Ajzen, 2015a). 
Theory of Planned Behavior was developed to predict behaviors that are completely not under individual control. Theory of Planned Behavior is based on the assumption that humans are rational creatures and use information that is possible for them, systematically. People think about the implications of their actions before they decide whether or not to do certain behaviors. TPB begins by looking at the intention to behave as the closest antecedent of a behavior. It is believed that the stronger a person's intention to display a certain behavior, the more successful he is to do it. Intention is a function of beliefs and / or important information about the tendency that displaying a certain behavior will lead to a specific result. Intention can change with time. The longer the distance between intention and behavior, the greater the tendency for a change in intention (Ajzen, 2015a).

\section{Consumer Purchasing Behavior}

Consumer behavior is the behavior shown by consumers in searching for, buying, using, evaluating, and stopping consumption of products, services and ideas (Schiffman et al., 2010). According to Kotler \& Armstrong (2008), consumer purchasing decisions are to buy the most preferred brand from various alternatives, but two factors can be between purchase intention and purchase decision (Kotler \& Armstrong, 2008). The first factor is the attitude of other people and the second factor is the situational factor. Therefore, purchase preferences and intentions do not necessarily result in an actual purchase. Purchasing decisions are problemsolving activities carried out by individuals in selecting suitable alternative behaviors from two or more alternative behaviors and are considered as the most appropriate action in buying by first going through the stages of the decision-making process (Kotler \& Armstrong, 2008).

Furthermore, Kotler \& Armstrong (2008) suggested five stages of consumer behavior in making purchasing decisions, namely: (1) Introduction of needs. The recognition of needs arises when consumers face a problem, which is a situation where there is a difference between the desired state and the actual situation. (2) Information seekers. Information seeking begins when consumers perceive that these needs can be met by buying and consuming products. Consumers will search for information stored in their memory (internal search) and search for information from outside (external search). (3) Evaluation of alternatives. Alternative evaluation is the process of evaluating product and brand choices, and selecting them according to consumer desires. In this process, consumers compare various selected brands that can provide benefits to them and the problems they face. (4) Purchase decision. After the steps above are carried out, the buyer will determine his attitude in making the decision whether to buy or not. If you choose to buy a product, in this case the consumer is faced with several alternative decision making such as product, brand, seller, place, price, seller, quantity and time. (5) Results. After buying a product, consumers will experience several levels of satisfaction and dissatisfaction. This stage can provide important information for the company whether the products and services that have been sold can satisfy consumers or not (Kotler \& Armstrong, 2008).

\section{Attitude}

Attitude is defined as a comprehensive evaluation of a concept by a person. Evaluation (evaluation) is a feedback effect on the level of intensity and relatively low motion. Evaluation can be created by affective or cognitive systems (Peter \& Olson, 2000). The influence system automatically produces affective responses including emotions, feelings, moods and evaluations of attitudes as an immediate, direct response to certain stimuli. Then through the classical conditioning process, the evaluation can be linked to a particular product or brand, thus creating an attitude. In general, the definition of attitude has in common that attitude is defined as an evaluation of someone, suggesting that attitudes show what consumers like and don't like. Attitudes are beliefs about certain behaviors and their consequences. Attitudes towards behavior are defined as positive or negative feelings for an individual to carry out a behavior or action. This is determined by assessing a person's beliefs about the consequences arising from the behavior and evaluating the consequences of those desires. Attitude is an overall evaluation of a particular action which shows how much someone likes or dislikes doing it. The attitude of a Muslim consumer reflects the overall evaluation of his likes or dislikes in carrying out Islamic faith (Rochmanto \& Widiyanto, 2014).

Attitude refers to the extent to which a person has favorable or unfavorable judgments or judgments on the intended behavior. As a general rule, the more favorable attitude and subjective with respect to behavior, and the greater the perceived behavioral control, the stronger must be the individual's intention to perform the considered behavior. The relative importance of perceived attitudes, subjective norms, and behavioral control in 
predicting expected intention varies across behaviors and situations. According to the expectation-value model, attitudes toward a behavior are determined by the total set of accessible behavioral beliefs that link the behavior to various outcomes and other attributes (Ajzen, 2015a). Attitude is also one of the important factors that influence the purchase intention of halal food productsbecause consumers who have positive attitudes towards halal products tend to have very high purchase intentions to buyhalal food products(Elseidi, 2018).

Purchase intentions of consumers come from consumer attitudes and assessments of a product as well as external factors of the product. Attitudes, judgments, and other external factors are very important factors in predicting consumer behavior. Purchase intention can measure how likely consumers are to buy a product, where the higher the purchase intention the higher the consumer's intention to buy the product (Maghfiroh, 2015). The results of the study (Abd-Rahman et al., 2015) prove that attitudes have a positive effect on intention use of halal products (Abd-Rahman et al., 2015). Research using Theory of Reasoned Action (TRA) found that attitudes are positively related to the intention to choose halal products among consumers (Mukhtar \& Butt, 2012). The above research results prove that attitudes have an effect on buying interest in halal products. Based on the description above, the hypothesis of this research is:

\section{H1: Attitudes have a positive effect on buying interest in halal products}

\section{E. Subjective Norms}

Subjective norms are determined by the presence of normative beliefs and the desire to follow (motivation to comply). Normative beliefs relate to expectations that come from referents or influential people and groups for individuals (significant others) such as a partner's parents, close friends, coworkers or others, depending on the behavior involved. So subjective norms are formed as a result of the individual's perception of existing social pressure to show or not a behavior. Individuals have the belief that certain individuals or groups will accept or not accept their actions. If individuals believe in what is the norm of the group, then the individual will comply and form behavior in accordance with the group. Subjective norms are not only determined by referents, but also by motivation to comply. In general, individuals who believe that most referents will approve of themselves displaying certain behaviors, and that they are motivated to follow certain behaviors, will feel social pressure to do so. Conversely, individuals who believe that most referents will not approve of themselves displaying certain behaviors, and lack of motivation to follow certain behaviors, will cause them to have a subjective norm that places pressure on themselves to avoid doing these behaviors (Ajzen, 1991). Subjective norms refer to consumers' perceptions of social normative drives, which can include family, friends, colleagues, relatives, or other significant groups. These samples can offer stress to the individual. Subjective norms are the social pressure a person feels to comply or disobey certain behaviors (Ajzen, 2015a).

If someone perceives that the people around him have a strong influence on buying halal food products, social pressure will arise to generate interest in buying products labeled halal. Conversely, the more students perceive that the people around them do not have a strong influence on buying halal food products, there tends to be no social pressure to generate interest in buying products labeled halal.

A predictor of social factors called subjective norms is the social pressure that is felt to meet expectations about involvement in a behavior that must influence the individual's intention to do or not to that behavior. If the social expectation is that people should perform in the behavior in question, then individuals should be more inclined to do so. Conversely, if the social expectation is that one should not perform in a behavior, then the individual should be inclined to do so. In this case, if the purchase of halal food is seen as socially desirable behavior, based on what other important people think about it, then individuals are more likely to purchase halal food. In this study, subjective norms are perceived social pressures that influence consumer decisions to buy halal food (Alam \& Sayuti, 2011). The research results of Bashir, Bayat, Olutuase, \& Abdul Latiff (2019), Alam \& Sayuti, (2011), and Afendi, Azizan, \& Darami (2014) prove that subjective norms have an effect on buying interest in halal products. Based on the description above, the hypothesis of this research is:

\section{H2: Subjective norms have a positive effect on buying interest in halal products}




\section{F. Perceived Behavioral Control}

Perceived behavioral control (perceived behavioral control) is an individual's perception of difficulty in performing certain behaviors. Perceived Behavioral Control describes feelings of self-efficacy or the ability of an individual to perform a behavior. Perceived Behavior Control is an individual's perception of the control the individual has with regard to certain behavior. Perceived Behavior Control is a belief about the presence or absence of factors that facilitate and prevent individuals from performing a behavior. Perceived Behavior Control is determined by an individual's past experiences and also an individual's estimate of how difficult or easy it is to perform a behavior. An individual's past experience of a behavior can be influenced by information obtained from other people, for example from the experiences of known people such as family, spouses and friends (Ajzen, 1991, 2005, 2008). Perceived Behavioral Control or commonly known as perceived behavior control is an individual's belief about the presence or absence of factors that support or prevent an individual from bringing up a behavior. The more a person feels there are many supporting factors and few inhibiting factors to be able to perform a behavior, the more control they feel over the behavior. So the more supporting factors a person has to buy food products labeled halal, the greater the intention to buy food products labeled halal.

Perceived behavioral control is the extent to which a person feels capable of engaging in the behavior. This has two aspects: how much control a person has over the behavior and how confident one is about being able to or not perform the behavior. It is determined by the individual's belief about the power of both situational and internal factors to facilitate the performance of the behavior. The more control a person feels about making a halal food purchase, the more likely he or she will. In this study, perceived behavioral control is the ability to buy halal food (Afendi et al., 2014). The results of research by Bashir, Bayat, Olutuase, \& Abdul Latiff (2019), Alam \& Sayuti, (2011), and Afendi, Azizan, \& Darami (2014) prove that perceptions of behavior control have an effect on buying interest in halal products. Based on the description above, the hypothesis of this research is:

\section{H3: Perception of behavior control has a positive effect on buying interest in halal products}

\section{G. Purchase Intention}

Interest is assumed to be a motivational factor that influences behavior. Intention is an indication of how hard a person is trying or how much effort is put into displaying a behavior. As a general rule, the harder a person intends to engage in a behavior, the more likely he is to actually engage in that behavior. The intention to behave can become actual behavior only if the behavior is under the control of the individual concerned. Individuals have the choice to decide certain behaviors or not at all (Maghfiroh, 2015). Purchase interest that consumers have comes from consumer attitudes and assessments of a product as well as external factors of the product. Attitudes, judgments, and other external factors are very important factors in predicting consumer behavior. Purchase intention can measure how likely consumers are to buy a product, where the higher the purchase intention, the higher the consumer's intention to buy the product (Maghfiroh, 2015).

Purchase interest reflects the short-term behavior of consumers in the future for future purchasing decisions (next shopping plan). Purchase interest is the most appropriate thing to predict consumer behavior. Purchase intention refers to the possibility of consumers buying a product. Purchase intention is an individual's conscious plan to make an effort to buy a product (Listyoningrum \& Albari, 2012). Purchasing interest refers to an individual's readiness and willingness to buy a particular product or service (Ajzen, 2005), and it can influence consumer purchasing decisions in the future. This can be considered as one of the cognitive behavioral mechanisms of consumers on how consumers intend to buy certain products (Bashir et al., 2019). Intention can be a reliable predictor of behavior. Purchasing behavior comes from adequate awareness of the product (Bashir et al., 2019). Based on the description above, the hypothesis of this research is:

\section{H4: Purchasing intention has a positive effect on the buying behavior of halal products}

\section{H. Halal Awareness}

Awareness is knowledge or understanding of a certain subject or situation, while awareness in the context of halal means understanding or knowing information about what is good or permissible for consumption and what is prohibited or not good for Muslims in the food we are consuming (Pramintasari \& Fatmawati, 2017). Halal 
awareness is an awareness of an individual regarding halal issues. Halal awareness is marked by the knowledge of a Muslim about what halal is (Aziz \& Chok, 2015). According to NAB Ahmad, Abaidah, \& Yahya, (2013) halal awareness is known based on understanding whether a Muslim is halal, knowing the correct slaughtering process, and prioritizing halal food for their consumption. Based on the above understanding, it can be concluded that halal awareness is a Muslim knowledge of the concept of halal, the halal process, and considers that consuming halal food is important for him.

The awareness of Muslims in Indonesia tends to increase accompanied by MUI data where the products registered for obtaining a halal certificate have also increased. Consumers begin to look for what is good and useful for themselves to consume. When people begin to realize that consuming halal food is important for themselves, this will have a positive impact on the interest in buying halal products. The greater the level of understanding of a Muslim towards halal, the more positive a Muslim's behavior will be regarding issues related to halal. This also affects the buying interest of Muslims to consume products in accordance with Islamic rules. Therefore, halal awareness increases the positive influence of attitudes on the interest in buying halal food products. The research results of Nurhasanah \& Hariyani (2017), Hayat Muhammad, Ahmad, Siddiquei, \& Haider, (2013), Bashir, Bayat, Olutuase, \& Abdul Latiff (2019) prove that halal awareness increases buying interest and purchasing behavior of halal products. Based on the description above, the hypothesis of this research is:

\section{H5: Halal awareness moderates the positive influence of interest in buying behavior of halal food products}

\section{Research Conceptual Framework}

According to (Sekaran \& Bougie, 2003) the theoretical framework is the foundation on which all research projects are based. From the theoretical framework can be formulated hypotheses that can be tested to determine whether the theory formulated is valid or not. Then the further it will be measured by appropriate statistical analysis. Referring to previous theory and research, there is a relationship between variables, which include attitude, subjective norm and perceived behavioral control, purchase intention, halal awareness and purchase behavior. The author builds a research model as follows:

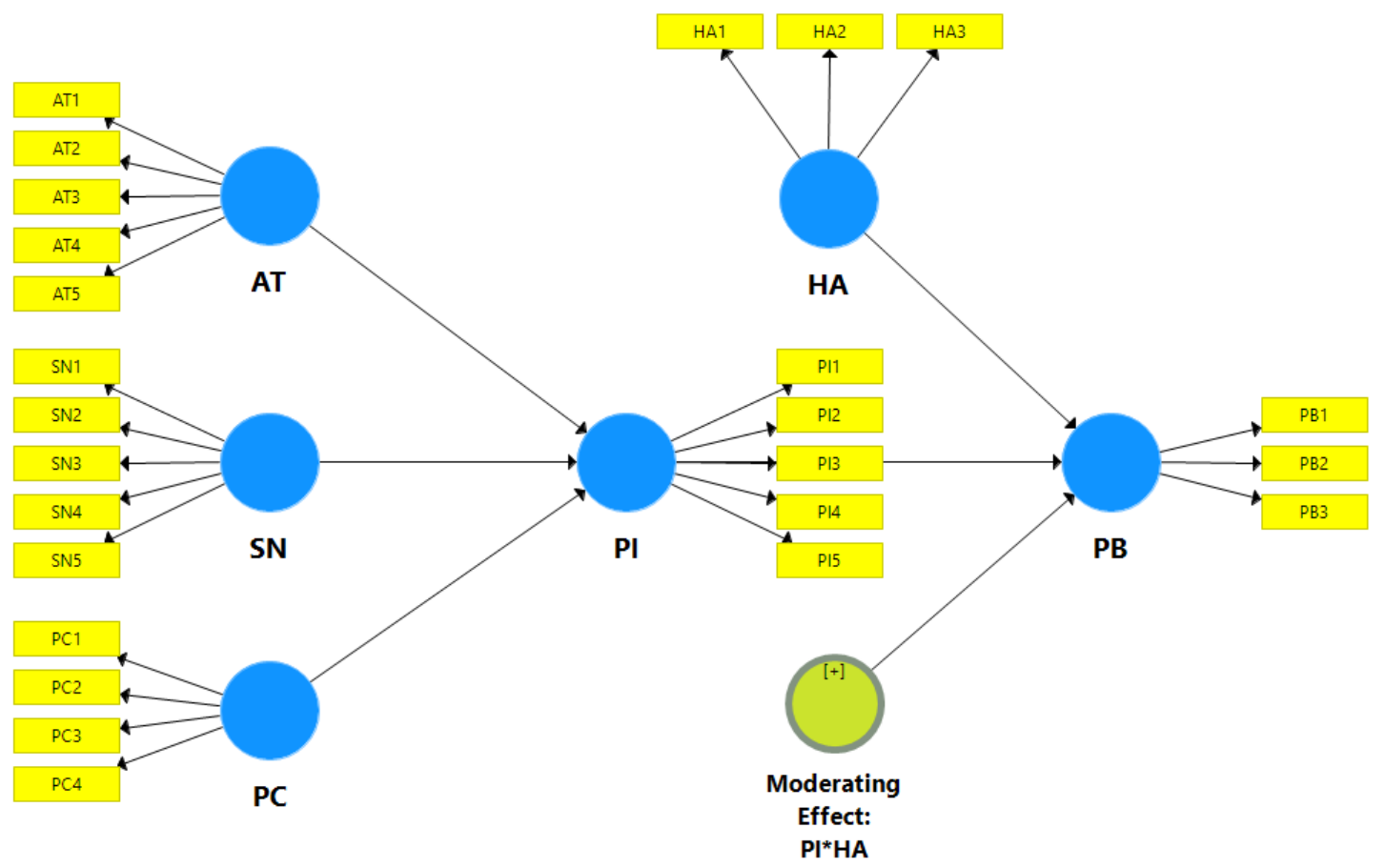

Figure 1. Research Model 


\section{METHODS}

\section{A. Definition of Operational Variable and Indicator}

The method used in this research is quantitative method. Data collection was carried out by distributing questionnaires to 410 working student populations at one of the private universities in Tangerang, Indonesia. The instrument used to measure attitude was adapted from (Abd-Rahman et al., 2015) by using 5 items (AT1AT5). Subjective norms were adapted from (Rachbini, 2018) using 5 items (SN1-SN5). Perceived behavioral control was adapted from (Rachbini, 2018) using 4 items (PC1-PC4). Purchase intention was adapted from (Abd-Rahman et al., 2015) using 5 items (PI1-PI5). Halal awareness was adapted from (Aziz \& Chok, 2013; Nurhasah et al., 2018) by using 3 items (HA1-HA3). Meanwhile, purchase behavior is adapted from (Ajzen, 1991) by using 3 items (PB1-PB3). The questionnaire is designed closed except for questions / statements regarding the identity of the respondent in the form of a semi-open questionnaire. Each closed question / statement item is given five answer options, namely: strongly agree (SS) score 5, agree (S) score 4, neutral (N) score 3, disagree (TS) score 2, and strongly disagree (STS) score 1. The method for processing data is by using PLS and using software SmartPLS version 3.0as its tool.

\section{B. Population and Sample}

The population in this study were 410 working students at one of the private universities in Tangerang, Indonesia. The questionnaires were distributed using simple random sampling technique. The results of questionnaires that were returned and valid were 211 samples.

\section{A. Sample Description}

\section{RESULTS AND DISCUSSION}

Table 1. Sample Descriptive Information

\begin{tabular}{llll}
\hline Criteria & & Total & \% \\
\hline Gender & Male & 129 & $61 \%$ \\
& Female & 82 & $39 \%$ \\
\hline Age (per December 2020) & $<20$ years old & 54 & $26 \%$ \\
& $20-25$ years old & 98 & $46 \%$ \\
& $>25$ years old & 59 & $28 \%$ \\
\hline Working Period & $<$ 1 year & 75 & $36 \%$ \\
& $1-5$ years & 102 & $48 \%$ \\
& $>5$ years & 33 & $16 \%$ \\
\hline
\end{tabular}

\section{B. Test Results of the Validity and Reliability of Research Indicators}

The testing phase of the measurement model includes testing for convergent, validity discriminant validity. Meanwhile, to test construct reliability, Cronbach's alpha value and composite reliability were used. The results of the PLS analysis can be used to test the research hypothesis if all indicators in the PLS model have been implemented to meet the requirements of convergent validity, discriminant validity and reliability test.

\section{Convergent Validity Testing Convergent}

Validity tests are carried out by looking at thevalue loading factor of each indicator against the construct. In most references, a factor weight of 0.5 or more is considered to have sufficiently strong validation to explain latent constructs (Chin, 1998; Ghozali, 2014; Hair et al., 2010). In this study, the minimum limit for loading factor the accepted is 0.5, provided that the AVE value of each construct is> 0.5 (Ghozali, 2014). Based on the results of SmartPLS 3.0 processing, all indicators have a value loading factor above 0.5. So thus, the convergent validity of this research model has met the requirements. The value of loadings, cronbach's alpha, composite reliability and AVE for each complete construct can be seen in Table 2 below: 


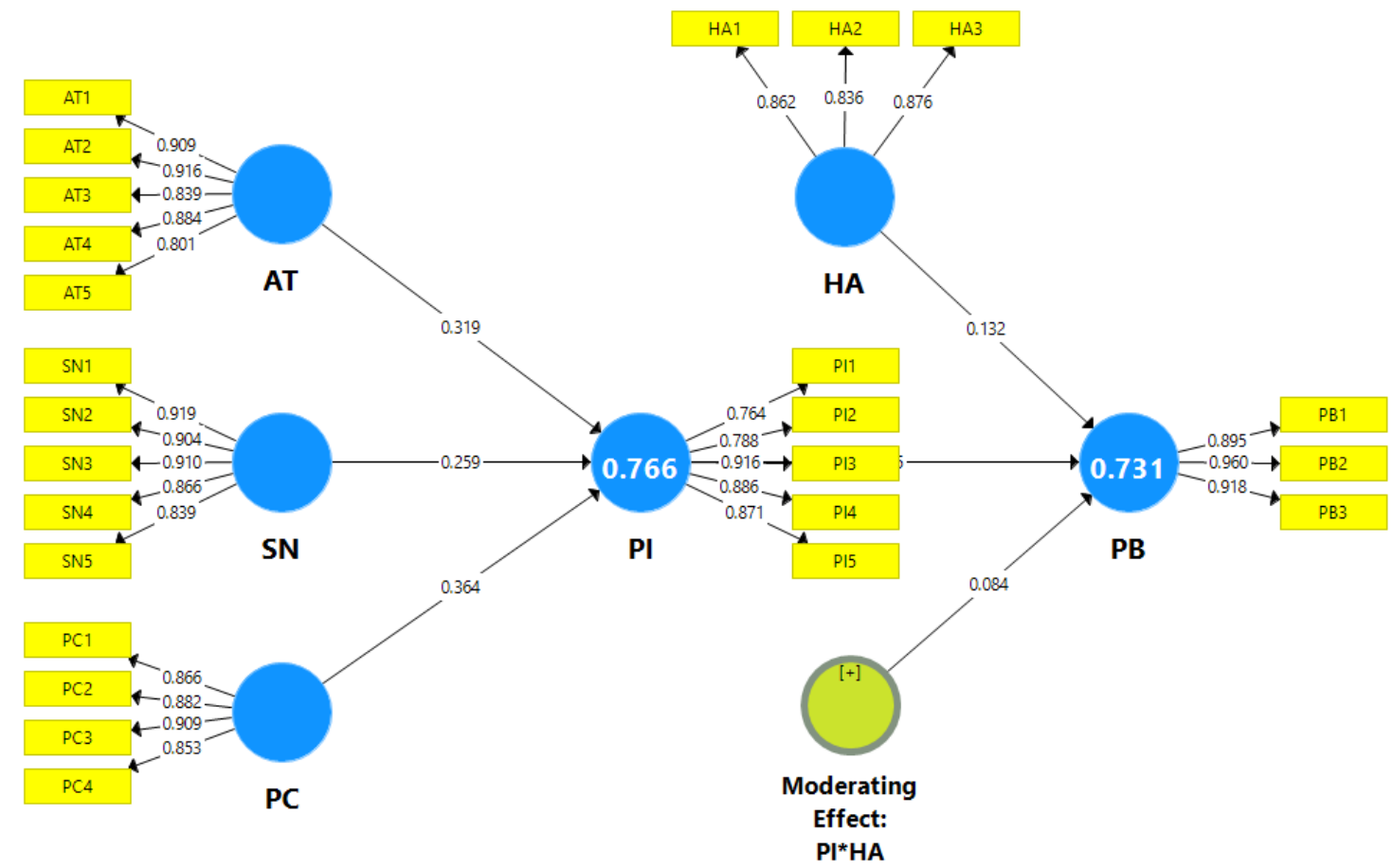

Figure 1. Research Model (Fit)

Table 2. Items Loadings, Cronbach's Alpha, Composite Reliability, and Average Variance Extracted (AVE)

\begin{tabular}{|c|c|c|c|c|c|}
\hline Variables & Items & Loadings & $\begin{array}{l}\text { Cronbach's } \\
\text { Alpha }\end{array}$ & $\begin{array}{l}\text { Composite } \\
\text { Reliability }\end{array}$ & AVE \\
\hline \multirow{5}{*}{$\begin{array}{l}\text { Attitude } \\
\text { (AT) }\end{array}$} & AT1 & 0.909 & \multirow{5}{*}{0.920} & \multirow[t]{5}{*}{0.940} & \multirow[t]{5}{*}{0.758} \\
\hline & AT2 & 0.916 & & & \\
\hline & AT3 & 0.839 & & & \\
\hline & AT4 & 0.884 & & & \\
\hline & AT5 & 0.801 & & & \\
\hline \multirow{5}{*}{$\begin{array}{l}\text { Subjective Norm } \\
\text { (SN) }\end{array}$} & SN1 & 0.919 & \multirow[t]{5}{*}{0.933} & \multirow[t]{5}{*}{0.949} & \multirow[t]{5}{*}{0.789} \\
\hline & SN2 & 0.904 & & & \\
\hline & SN3 & 0.910 & & & \\
\hline & SN4 & 0.866 & & & \\
\hline & SN5 & 0.839 & & & \\
\hline \multirow{4}{*}{$\begin{array}{l}\text { Perceived Control } \\
(P C)\end{array}$} & PC1 & 0.866 & \multirow[t]{4}{*}{0.900} & \multirow[t]{4}{*}{0.931} & \multirow[t]{4}{*}{0.770} \\
\hline & PC2 & 0.882 & & & \\
\hline & PC3 & 0.909 & & & \\
\hline & PC4 & 0.853 & & & \\
\hline \multirow{5}{*}{$\begin{array}{l}\text { Purchase Intention } \\
\text { (PI) }\end{array}$} & PI1 & 0.764 & \multirow[t]{5}{*}{0.900} & \multirow[t]{5}{*}{0.927} & \multirow[t]{5}{*}{0.717} \\
\hline & PI2 & 0.788 & & & \\
\hline & PI3 & 0.916 & & & \\
\hline & PI4 & 0.886 & & & \\
\hline & PI5 & 0.871 & & & \\
\hline \multirow{3}{*}{$\begin{array}{l}\text { Halal Awareness } \\
\text { (HA) }\end{array}$} & HA1 & 0.862 & \multirow[t]{3}{*}{0.821} & \multirow[t]{3}{*}{0.893} & \multirow[t]{3}{*}{0.736} \\
\hline & HA2 & 0.836 & & & \\
\hline & HA3 & 0.876 & & & \\
\hline \multirow{3}{*}{$\begin{array}{l}\text { Purchase Behavior } \\
\text { (PB) }\end{array}$} & PB1 & 0.895 & \multirow[t]{3}{*}{0.914} & \multirow[t]{3}{*}{0.946} & \multirow[t]{3}{*}{0.855} \\
\hline & PB2 & 0.960 & & & \\
\hline & PB3 & 0.918 & & & \\
\hline
\end{tabular}




\section{Discriminant Validity Testing}

Discriminant validity is carried out to ensure that each concept of each latent variable is different from other latent variables. The model has good discriminant validity if the AVE square value of each exogenous construct (the value on the diagonal) exceeds the correlation between this construct and other constructs (values below the diagonal) (Ghozali, 2014). The results of testing discriminant validity using the AVE square value, namely by looking at the Fornell-Larcker Criterion Value (Fornell \& Larcker, 1981b), were obtained as follows:

Table 3. Discriminant Validity

\begin{tabular}{lrrrrrrr}
\hline \multicolumn{1}{c}{ Variables } & AT & HA & PI*HA & PB & PC & PI & SN \\
\hline & & & & & & & \\
Attitude & $\mathbf{0 . 8 7 1}$ & & & & & & \\
Halal Awareness & 0.687 & $\mathbf{0 . 8 5 8}$ & & & & & \\
Moderating Effect: PI*HA & 0.188 & 0.188 & $\mathbf{1 . 0 0 0}$ & & & & \\
Purchase Behavior & 0.729 & 0.655 & 0.179 & $\mathbf{0 . 9 2 4}$ & & & \\
Perceived Control & 0.787 & 0.727 & 0.232 & 0.802 & $\mathbf{0 . 8 7 8}$ & & \\
Purchase Intention & 0.815 & 0.679 & 0.085 & 0.843 & 0.818 & $\mathbf{0 . 8 4 7}$ & \\
Subjective Norm & 0.807 & 0.698 & 0.261 & 0.727 & 0.784 & 0.802 & $\mathbf{0 . 8 8 8}$ \\
& & & & & & & \\
\hline
\end{tabular}

Table 4. Collinearity Statistics (VIF)

\begin{tabular}{|c|c|c|c|c|c|c|c|}
\hline Variables & $\mathbf{A T}$ & HA & PI*HA & PB & PC & PI & SN \\
\hline Attitude & & & & & & 3.480 & \\
\hline Halal Awareness & & & & 1.917 & & & \\
\hline Moderating Effect: PI*HA & & & & 1.040 & & & \\
\hline Purchase Behavior & & & & & & & \\
\hline Perceived Control & & & & & & 3.151 & \\
\hline Purchase Intention & & & & 1.863 & & & \\
\hline Subjective Norm & & & & & & 3.449 & \\
\hline
\end{tabular}

The results of the discriminant validity test in Table 3 above show that all constructs have a square root value of AVE above the correlation value with other latent constructs (through the Fornell-Larcker criteria). Likewise, the cross-loading value of all items from an indicator is greater than the other indicator items as mentioned in Table 4, so it can be concluded that the model has met the discriminant validity (Fornell \& Larcker, 1981a).

Furthermore, a collinearity evaluation is carried out to determine whether there is collinearity in the model. To find collinearity, it is necessary to calculate the VIF of each construct. If the VIF score is higher than 5, then the model has collinearity (Hair et al., 2014). As shown in Table 4, all VIF scores are less than 5, meaning that this model has no collinearity.

\section{Testing of Construct Reliability}

Construct reliability can be assessed from the Cronbach's alpha value and the composite reliability of each construct. The recommended values composite reliability and Cronbach alpha are more than 0.7 (Ghozali, 2014). The reliability test results in table 2 above show that all constructs have values of composite reliability and Cronbach alpha greater than 0.7 (> 0.7). In conclusion, all constructs have met the required reliability. 


\section{Hypothesis Testing}

Hypothesis testing in PLS is also called the inner model test. This test includes a significance test for direct and indirect effects as well as measuring the magnitude of the influence of exogenous variables on endogenous variables. The effect test was performed using the t-statistic test in the analysis model partial least square (PLS) using the software SmartPLS 3.0. With the technique bootstrapping, the values for $R$ Square andsignificance test values as shown in the table below:

Table 5. R Square Value

\begin{tabular}{lll}
\hline & R Square & R Square Adjusted \\
\hline Purchase Behavior (PB) & 0.731 & 0.727 \\
Purchase Intention (PI) & 0.766 & 0.763 \\
& & \\
\hline
\end{tabular}

Table 6. Hypothesis Testing

\begin{tabular}{llccccc}
\hline Hypotheses & Relationship & Beta & SE & T Statistics & P-Values & Decision \\
\hline H1 & AT -> PI & 0.319 & 0.069 & 4.629 & 0.000 & Supported \\
H2 & SN -> PI & 0.259 & 0.074 & 3.496 & 0.001 & Supported \\
H3 & PC -> PI & 0.364 & 0.096 & 3.806 & 0.000 & Supported \\
H4 & PI -> PB & 0.745 & 0.048 & 15.467 & 0.000 & Supported \\
& & & & & & \\
H5 & PI*HA -> PB & 0.084 & 0.039 & 2.132 & 0.033 & Supported \\
& & & & & & \\
\hline
\end{tabular}

Based on Table 5 above, the value of $R$ SquarePurchase intention (PI) is 0.766 , which means that the variable purchase intention (PI) can be explained by the variable attitude (AT), subjective norm (SN) and perceived control (PI) of $76.6 \%$, while the remaining $23.4 \%$ is explained by other variables not discussed in this study. Value of $R$ SquarePurchase behavior (PB) is 0.731 , which means that the purchase behavior (PB) variable can be explained by the variable purchase intention (PI) and halal awareness (HA).73.1\%, while the remaining $26.9 \%$ is explained by other variables not discussed in this study. Meanwhile, Table 6 shows the T Statistics and $P$-Values which show the influence between the research variables that have been mentioned.

\section{Discussion}

\section{The Effect of Attitudes on Purchase Intention for Halal Food Products}

The results of this study prove that attitudes have a positive effect on buying interest in halal food products. The better the consumer's attitude towards halal food will increase the interest in buying halal food products for working students in Indonesia. Azam (2016) states that attitude is one of the important factors affecting the purchase intention of food products halal because consumers who have a positive attitude towards halal products tend to have very high purchase intentions to buy food products halal. The results of research by AbdRahman et al. (2015) and Hasan \& Suciarto (2020) prove that attitudes have a positive effect on the intention to use halal products. Research conducted by Syrotyuk et al. (2018) on attitudes towards purchasing halal products confirms that attitudes, subjective norms and behavioral control have a significant impact on the intention to buy 
halal food. These results are consistent with research by Syukur \& Nimsai (2018) and Teng et al. (2018) proved that attitudes have an effect on buying interest in halal products.

\section{The Influence of Subjective Norms on Purchase Intention for Halal Food Products}

The results of this study prove that subjective norms have a positive effect on buying interest in halal food products. The higher the influence of the reference group on halal food, the higher the interest in purchasing halal food. Subjective norms are determined by the presence of normative beliefs and the desire to follow (motivation to comply). Normative beliefs relate to expectations that come from referents or influential people and groups for individuals (significant others) such as a partner's parents, close friends, coworkers or others, depending on the behavior involved. So subjective norms are formed as a result of the individual's perception of existing social pressure to show or not a behavior. Individuals have the belief that certain individuals or groups will accept or not accept their actions. If individuals believe in what is the norm of the group, then the individual will comply and form behavior in accordance with the group. Subjective norms are not only determined by referents, but also by motivation to comply. In general, individuals who believe that most referents will approve of themselves displaying certain behaviors, and that they are motivated to follow certain behaviors, will feel social pressure to do so. On the other hand, individuals who believe that most referents will not approve of themselves displaying certain behaviors, and lack of motivation to follow certain behaviors, will cause them to have a subjective norm that places pressure on themselves to avoid doing these behaviors (Ajzen, 2008).

A predictor of social factors called subjective norms is the social pressure that is felt to meet expectations about involvement in a behavior that must influence an individual's intention to do or not to that behavior. If the social expectation is that people should perform in the behavior in question, then individuals should be more inclined to do so. Conversely, if the social expectation is that one should not perform in a behavior, then the individual should be inclined to do so. In this case, if the purchase of halal food is seen as socially desirable behavior, based on what other important people think about it, then individuals are more likely to purchase halal food. In this study, subjective norms are perceived social pressures that influence consumer decisions to buy halal food (Haro, 2016; Iranmanesh et al., 2019; Soon \& Wallace, 2017). This result is in accordance with the research of Bashir et al., (2019, Latiff et al. (2019), Maichum et al. (2017), and Marmaya et al. (2019) which have proven that subjective norms have an effect on buying interest in halal products.

\section{The Effect of Perception of Behavioral Control on Purchase Intention for Halal Food Products}

The results of this study prove that Perceptions of Behavior Control have a positive effect on buying interest in halal food products. The higher the Perception of Behavioral Control towards halal food, the higher the interest in purchasing halal food. Perceived behavioral control(perceivedbehavioralcontrol)is an individual's perception of difficulty in performing certain behaviors. Perceived Behavioral Control describes feelings of self-efficacy or the ability of an individual to perform a behavior. Perceived Behavior Control is an individual's perception of the control the individual has with regard to certain behavior. Perceived Behavior Control is a belief about the presence or absence of factors that facilitate and prevent individuals from performing a behavior. Perceived Behavior Control is determined by an individual's past experiences and also an individual's estimate of how difficult or easy it is to perform a behavior. An individual's past experience with a behavior can be influenced by information obtained from other people, for example from the experiences of known people such as family, spouses and friends (Ajzen, 1991, 2015c, 2015b, 2020; De Leeuw et al., 2015). The more control a person feels about making a halal food purchase, the more likely he or she will. In this study, perceived behavioral control is the ability to buy halal food (Ali et al., 2017; Elseidi, 2018; Hong et al., 2019; Vanany et al., 2019). These results are consistent with the research of Bashir et al. (2019) and Effendi et al. (2020) which has proven that perceptions of behavior control have an effect on buying interest in halal products.

\section{The Influence of Purchase Intention for Halal Food Products on Purchasing Behavior of Halal Food Products}

The results of this study prove that buying interest has a positive effect on purchasing behavior towards halal food products. The higher the buying interest in halal food will increase the buying behavior of halal food. Interest is assumed to be a motivational factor that influences behavior. Intention is an indication of how hard a person is trying or how much effort is put into displaying a behavior. As a general rule, the harder a person intends to engage in a behavior, the more likely he is to actually engage in that behavior. The intention to 
behave can become actual behavior only if the behavior is under the control of the individual concerned. Individuals have the choice to decide certain behaviors or not (Mustafar et al., 2018). Purchase interest is an individual's conscious plan to make an effort to buy a product (Listyoningrum \& Albari, 2012). Purchase intention refers to an individual's readiness and willingness to purchase a particular product or service (Ajzen, $2015 b, 2015 c, 2020)$, and it can influence consumer purchasing decisions in the future. These results are consistent with the research of Bashir et al. (2019) and Effendi et al. (2020) which proves that interest is a reliable predictor of behavior in purchasing behavior of halal products

\section{The Effect of Halal Awareness in Moderating the Relationship between Purchasing Interest in Halal Food Products on Purchasing Behavior of Halal Food Products}

The results of this study prove that halal awareness moderates the influence of purchase intention on purchasing behavior towards halal food products. The higher the awareness of halal will increase the relationship between buying interest and buying behavior of halal food. Awareness is knowledge or understanding of a certain subject or situation, while awareness in the context of halal means understanding or knowing information about what is good or permissible for consumption and what is prohibited or not good for Muslims in the food we will consume (Aziz \& Chok, 2013). These results are consistent with the research of Abdullah \& Razak (2019) and Asif et al. (2018) which proves that halal awareness moderates purchase intention towards purchasing behavior of halal products.

\section{CONCLUSIONS}

Based on the results of the research as previously described, several conclusions can be drawn, namely attitudes, subjective norms, perceptions of behavioral control have a positive effect on buying interest in halal products. Purchasing interest has a positive effect on purchasing behavior, and in this study it proves that halal awareness is able to moderate the effect of purchase intention on purchasing behavior towards halal food products. The higher the awareness of halal will increase the relationship between buying interest and buying behavior of halal food. The results of this study also show that the importance of paying attention to halal awareness in the form of increasing the relationship between buying interest and buying behavior of halal food products so that halal food producers must be able to increase the perception of halal awareness of every consumer.

\section{REFERENCES}

[1] Abd-Rahman, A., Asrarhaghighi, E., \& Ab-Rahman, S. (2015). Consumers and Halal cosmetic products: knowledge, religiosity, attitude and intention. Journal of Islamic Marketing, 6(1), 148-163. https://doi.org/10.1108/JIMA-09-2013-0068

[2] Abdullah, R., \& Razak, L. A. (2019). The effect of halal foods awareness on purchase decision with religiosity as a moderating variable. Journal of Islamic Marketing.

[3] Ajzen, I. (1991). The Theory of Planned Behavior. Organizational Behavior and Human Decision Processes, 50, $179-211$. https://doi.org/https://doi.org/10.1016/0749-5978(91)90020-T

[4] Ajzen, I. (2015a). Consumer attitudes and behavior: the theory of planned behavior applied to food consumption decisions. Consumer Attitudes and Behavior: The Theory of Planned Behavior Applied to Food Consumption Decisions, 70(2), 121-138. https://doi.org/10.13128/REA-18003

[5] Ajzen, I. (2015b). Consumer attitudes and behavior: the theory of planned behavior applied to food consumption decisions. Italian Review of Agricultural Economics, 70(2), 121-138.

[6] Ajzen, I. (2015c). The theory of planned behaviour is alive and well, and not ready to retire: a commentary on Sniehotta, Presseau, and Araújo-Soares. Health Psychology Review, 9(2), 131-137.

[7] Ajzen, I. (2020). The theory of planned behavior: Frequently asked questions. Human Behavior and Emerging Technologies, 2(4), 314-324.

[8] Ali, A., Xiaoling, G., Sherwani, M., \& Ali, A. (2017). Factors affecting Halal meat purchase intention. British Food Journal.

[9] Alserhan, B. A. (2015). The principles of Islamic marketing. Ashgate Publishing, Ltd.

[10] Ambali, A. R., \& Bakar, A. N. (2014). People's awareness on halal foods and products: Potential issues for policy-makers. ProcediaSocial and Behavioral Sciences, 121(19), 3-25.

[11] Asif, M., Xuhui, W., Nasiri, A., \& Ayyub, S. (2018). Determinant factors influencing organic food purchase intention and the 
moderating role of awareness: A comparative analysis. Food Quality and Preference, 63, 144-150.

[12] Azam, A. (2016). An empirical study on non-Muslim's packaged halal food manufacturers: Saudi Arabian consumers' purchase intention. Journal of Islamic Marketing, 7(4), 441-460. https://doi.org/10.1108/JIMA-12-2014-0084

[13] Aziz, Y. A., \& Chok, N. V. (2013). The Role of Halal Awareness, Halal Certification, and Marketing Components in Determining Halal Purchase Intention Among Non-Muslims in Malaysia: A Structural Equation Modeling Approach. Journal of International Food \& Agribusiness Marketing, 25(1), 1-23. https://doi.org/10.1080/08974438.2013.723997

[14] Bashir, A. M., Bayat, A., Olutuase, S. O., \& Abdul Latiff, Z. A. (2019). Factors affecting consumers' intention towards purchasing halal food in South Africa: a structural equation modelling. Journal of Food Products Marketing, 25(1), 26-48. https://doi.org/10.1080/10454446.2018.1452813

[15] Chin, W. (1998). The Partial Least Squares Approach to Structural Equation Modeling (E. Modern Methods for Business Research, In: G. A. Marcoulides (ed.)). Lawrence Erlbaum Associates Publisher.

[16] De Leeuw, A., Valois, P., Ajzen, I., \& Schmidt, P. (2015). Using the theory of planned behavior to identify key beliefs underlying proenvironmental behavior in high-school students: Implications for educational interventions. Journal of Environmental Psychology, 42 , $128-138$.

[17] Effendi, I., Murad, M., Rafiki, A., \& Lubis, M. M. (2020). The application of the theory of reasoned action on services of Islamic rural banks in Indonesia. Journal of Islamic Marketing, Vol. ahead(No. ahead-of-print). https://doi.org/https://doi.org/10.1108/JIMA-022020-0051

[18] Elseidi, R. I. (2018). Determinants of halal purchasing intentions: evidences from UK. Journal of Islamic Marketing.

[19] Endah, N., Daryanti, S., \& Hati, S. R. H. (2017). Young Adult Muslim Consumer Intention to Purchase Halal Cosmetics: Application of the Theory of Planned Behavior. 21(Icmesd), 569-573. https://doi.org/10.2991/icmesd-17.2017.102

[20] Fornell, C., \& Larcker, D. F. (1981a). Evaluating Structural Equation Models with Unobservable Variables and Measurement Error. Journal of Marketing Research, 18(1), 39. https://doi.org/10.2307/3151312

[21] Fornell, C., \& Larcker, D. F. (1981b). Evaluating Structural Equation Models with Unobservable Variables and Measurement Error. Journal of Marketing Research, 18(1), 39-50. https://doi.org/10.1177/002224378101800104

[22] Ghozali, I. (2014). Structural Equation Modeling, Metode Alternatif dengan Partial Least Square (PLS) (4th ed.). Badan Penerbit Universitas Diponegoro.

[23] Hair, J. F., Black, W. C., Babin, B. J., \& Anderson, R. E. (2010). Multivariate Data Analysis (7th ed.). Pearson Prentice Hall.

[24] Hair, J. F., Hult, G. T., Ringle, C. M., \& Sarstedt, M. (2014). A primer partial least squaresstructural equation modeling (PLS-SEM). SAGE Publications.

[25] Haro, A. (2016). Understanding TPB model, availability, and information on consumer purchase intention for halal food. International Journal of Business and Commerce, 5(8), 47-56.

[26] Hasan, H. N., \& Suciarto, S. (2020). The Influence of Attitude, Subjective Norm and Perceived Behavioral Control towards Orga nic Food Purchase Intention. Journal of Management and Business Environment (JMBE), l(2), 132. https://doi.org/10.24167/jmbe.v1i2.2260

[27] Hong, M., Sun, S., Beg, A. B. M. R., \& Zhou, Z. (2019). Determinants of halal purchasing behaviour: evidences from China. Journal of Islamic Marketing.

[28] Iranmanesh, M., Mirzaei, M., Hosseini, S. M. P., \& Zailani, S. (2019). Muslims' willingness to pay for certified halal food: an extension of the theory of planned behaviour. Journal of Islamic Marketing.

[29] Jonathan, W., \& Liu, J. (2010). Shaping Halal into a Brand. Journal of Islamic Marketing, 1(2), $107-123$.

[30] Kotler, P., \& Armstrong, G. (2008). Prinsip-prinsip Pemasaran (Jilid 1, Edisi 12). Jakarta: Erlangga.

[31] Lada, S., Tanakinjal, G. H., \& Amin, H. (2009). Predicting intention to choose halal products using theory of reasoned action. International Journal of Islamic and Middle Eastern Finance and Management.

[32] Latiff, Z. A. A., Masril, M. V., Vintisen, R., Baki, M. Z., \& Muhamad, N. (2019). Consumers' intention towards halal food in low-cost airlines in Kelantan, Malaysia. Journal of Contemporary Research in Social Sciences, 1(4), 82-86.

[33] Listyoningrum, A., \& Albari, A. (2012). Analisis Minat Beli Konsumen Muslim Terhadap Produk yang Tidak Diperpanjang Sertifikat Halalnya. Jurnal Ekonomi \& Keuangan Islam, 2(1), 40-51.

[34] Maghfiroh, M. (2015). Faktor-Faktor yang Memengaruhi Niat Membeli Makanan Kemasan Berlabel Halal LPPOM-MUI. Jurnal Economia, 11(2), 169-176. 
[35] Maichum, K., Parichatnon, S., \& Peng, K.-C. (2017). The influence of attitude, knowledge and quality on purchase intention towards halal food: A case study of young non-Muslim consumers in Thailand. IRA-International Journal of Management \& Social Sciences, $6(3), 354-364$.

[36] Majid, M. A. A., Abidin, I. H. Z., Majid, H. A. M. A., \& Chik, C. T. (2015). Issues of Halal Food Implementation in Malaysia. Journal of Applied Environmental and Biological Sciences, 5(6S), 50-56.

[37] Marmaya, N. H., Zakaria, Z., \& Mohd Desa, M. N. (2019). Gen Y consumers' intention to purchase halal food in Malaysia: a PLS SEM approach. Journal of Islamic Marketing, 10(3), 1003-1014. https://doi.org/10.1108/JIMA-08-2018-0136

[38] Mohd Suki, N., \& Abang Salleh, A. S. (2018). Mediating effect of Halal image on Muslim consumers' intention to patronize retail stores: Some insights from Malaysia. Journal of Islamic Marketing, 9(2), 338-355. https://doi.org/10.1108/JIMA-02-2017-0014

[39] Mukhtar, A., \& Butt, M. M. (2012). Intention to choose Halal products: the role of religiosity. Journal of Islamic Marketing.

[40] Mustafar, M., Ismail, R. M., Othman, S. N., \& Abdullah, R. (2018). A study on Halal cosmetic awareness among Malaysian cosmetics manufacturers. International Journal of Supply Chain Management, 7(5), 492-496.

[41] Nurhasah, S., Munandar, J. M., \& Syamsun, M. (2018). Faktor-Faktor yang Mempengaruhi Minat Beli Produk Makanan Olahan Halal pada Konsumen. Jurnal Manajemen Dan Organisasi, 8(3), 250-260. https://doi.org/10.29244/jmo.v8i3.22473

[42] Peter, J. P., \& Olson, J. C. (2000). Consumer behavior: Perilaku konsumen dan strategi pemasaran. Jakarta: Erlangga.

[43] Rachbini, W. (2018). The Relationship of Attitude, Subjective Norm, Perceived Behavioral Control on Halal Food Purchasing Behavior in Jakarta. IOSR Journal of Business and Management (IOSR-JBM), 20(1), 28-37. https://doi.org/10.9790/487X2001082837

[44] Rochmanto, B. Al, \& Widiyanto, I. (2014). Pengaruh Pengetahuan Produk Dan Norma Religius Terhadap Sikap Konsumen Dalam Niat Mengkonsumsi Produk Makanan Dan Minuman Halal (Studi Kasus di Kota Semarang). Fakultas Ekonomika dan Bisnis.

[45] Schiffman, L., Kanuk, L., \& Wisenblit, J. (2010). Consumer behavior 10th edition. Prentice Hall.

[46] Sekaran, U., \& Bougie, R. (2003). Research Methods For Business: A Skill Building Approach (Sixth edit). John Wiley and Sons, Inc.

[47] Soon, J. M., \& Wallace, C. (2017). Application of theory of planned behaviour in purchasing intention and consumption of Halal food. Nutrition \& Food Science.

[48] Syrotyuk, Leshchak, R. L., \& Dorosh. (2018). Experimental and Analytic Investigation of the Hydrogenation of Pipe Steels. Materials Science, 53(6), 811-817. https://doi.org/10.1007/s11003-018-0140-0

[49] Syukur, M., \& Nimsai, S. (2018). Factors influencing the purchase intention of halal packaged food in Thailand. International Journal of Supply Chain Management, 7(4), 1-6.

[50] Teng, P. K., Jamaliah, W., \& Jusoh, W. (2017). Why buying Halal labelled food? Understanding the spending behavior of non-Muslim consumers in Malaysia. International Journal of Business and Management, 1(2), 78-85. https://doi.org/10.26666/rmp.ijbm.2017.2.12

[51] Teng, P. K., Jamaliah, W., \& Jusoh, W. (2018). A Study of Factors Affecting Consumer Purchase Intention Towards Halal Labelled Cosmetics and Personal Care Products in Malaysia. E-Proceeding Of The 1st International Conference On Halal Global (ICOHG 2018), March, 26-27. https://worldconferences.net

[52] Vanany, I., Soon, J. M., Maryani, A., \& Wibawa, B. M. (2019). Determinants of halal-food consumption in Indonesia. Journal of Islamic Marketing. 